\title{
Air Asia: From Regional to Global
}

\author{
Dr. Khaliq Ahmad Mohammad \\ Department of Business Administration, AACSB Accredited College of Business and Economics, Qassim University, Buraidah, \\ Saudi Arabia \\ *Correspondence: Dr. Khaliq Ahmad Mohammad, K.ISRAIL@.qu.edu.sa
}

\begin{abstract}
In February 2009, Tony Fernandez, the founder of AirAsia was not bothered by the company's mass order of 175 new aircraft for its AirAsia-X long-haul services. He could not resist the concern over the aircraft deferment to Thailand and Indonesia in 2011 because of the relocation of the low-cost carrier terminal in Sepang before AirAsia was forced to move to KLIA2. Such a situation would surely increase its operating costs exponentially. He also knew he was facing an economic downturn and the high competition, particularly for his AirAsia-X business. Major rivals of AirAsia-X in the region were Singapore Tiger Airways, Cebu Pacific Air of the Philippines and a global competitor was EasyJet in Europe had just launched aggressive campaigns and promotions which would affect its long-haul business. He was certain that the company would achieve his dream to spread its wings all over the world. However, he realized that the company's operating costs and competition with other airliners that joined the club of no-frills airlines based on a national and international level presently had escalated. He knew he had to act now. If you were Tony Fernandez, what would you do in this scenario was a question that needs an answer? This is an issue of strategic choice of divesting or integration as the strategic options are limited in the short as well as long run. The AirAsia case study has the main objective of sharing impact of the covid-19 pandemic devastating impact on the airliners. It is a significant study in terms of impact on economy, tourism and hospitality industry in general and Malaysia in particular.
\end{abstract}

Keywords: Air Asia, ASEAN Countries, Covid-19, Tourism, Branding

\section{ARTICLE INFORMATION}

Author(s): Dr. Khaliq Ahmad Mohammad

Received: 11 Dec, 2020; Accepted: 12 Jan, 2021; Published: 29 Jan, 2021 e-ISSN: 2347-4696;

Paper Id: BMN-IJBMR-2021-1;

Citation: doi.org/10.37391/IJBMR.090101

Webpage-link:https:/ijbmr.forexjournal.co.in/archive/volume-9/ijbmr-090101.html

\section{BRIEF BACKGROUND}

Air Asia originated from Malaysia for one ringgit company with the debt-ridden entity sold by the government to transform it as a private carrier to answer an increasing demand for promoting the tourism industry. With a brand image of a low-cost carrier, it had a slogan "Now everyone can fly" as being a no-frills airline, the airline positioned itself well. It branched out in the neighborhood as an independent entity in ASEAN countries. However, the success brought more success hence AirAsia X tried its luck beyond the region. AirAsia's presence in regional skies became a formidable contender to short-distance routes of the national and regular airlines such as Malaysian Airlines which faced the brunt of the competition.

AirAsia Bhd has performed well as a low cost carrier in the Asian region over a period of time. Since 2006-2007, the management of the company decided to move into new routes in the region and eventually global market. This case study objective is to compare prior and after the expansion, the effectiveness of the old strategy of centralized and remote control from Kuala Lumpur, with the new realities and airline industry future as old direction was set by Air Asia including AirAsia-X and the affiliates. Air Asia India is the newbie and part of brand positioning beyond the region.
Under the stewardship of Sunil Bhaskaran AirAsia India, commenced operation on 12 June 2014. This is a joint venture between Indian conglomerate Tata for $51 \%$ and Air Asia keeping $49 \%$ as an investment beyond the region to enjoy operation connecting major Indian cities Mumbai, Calcutta and New Delhi from its hub in Bengaluru.

\subsection{The Issue at Hand}

Last September, Tony Fernandes, owner of AirAsia, had a round of meetings with the Tata Sons management. The Tata's proposed a fundamental change on how the joint venture would operate in India. Fernandes was not comfortable with the idea. Tony's style is always to have full control. This situation coupled with the present political dispensation of India's unfriendly attitudes with a Malaysian entrepreneur, Tony Fernandes, turned out to become a major concern in the board room that needs attention.

\section{AIRASIA INDIA AND OVERVIEW OF THE INDUSTRY}

Years before AirAsia India was conceptualized, Fernandes had wanted to start a car company and had approached Ratan Tata an Indian conglomerate, for a tie-up with Jaguar Land Rover. No car firm project materialized. However AirAsia India took off to the Indian sky as a partnership between Ratan Tata and Tony Fernandes. Although friendship and trust between Tatas and Tony Fernandes existed but the former wanted to replicate the success of the Malaysian and South East Asian aviation experience of AirAsia in Indian sky. But Tony's style of staying in control is AirAsia's integral part of business plan created storm in a cup of tea. 


\subsection{Competition in Low-Cost Airlines}

As it is of common knowledge that AirAsia group have four other affiliates - Thailand, Indonesia, Philippines and Japan. These companies primarily complement the business model for the Malaysian parent. This is a typical style of combined business model of East (Japan) and West (Europe). The AirAsia typically tags a fee for almost everything ranging from using for the brand, route being chosen and allowing the partners to use single reservation platform for booking. Under the slogan of everyone can fly, Air Asia and its affiliates in the region have been successful in attracting otherwise shrinking middle class and lower upper-class target destination plus the site seeing the market. Coupled with MTC (Malaysian Tourism Corporation) in promoting Malaysian tourism industry, Air Asia has grown very fast from point to point destination without any further connectivity.

Competitor Tiger Airways operated services to regional destinations in South Asian countries Bangladesh, Sri Lanka and India as well as Southeast Asia, Indonesia, Thailand, the Philippines, from its main base at Singapore Changi Airport.

Similarly, EasyJet Plc styled as EasyJet, founded in March 1995, London, United Kingdom with subsidiaries in EasyJet Switzerland, EasyJet Europe, is a British low-cost airline group headquartered at London Luton Airport.

Another low cost competitor, Cebu Pacific Air, Inc., headquartered at Ninoy Aquino International Airport (Manila), with Subsidiaries located at Cebu, Philippine Academy for Aviation Training, Inc was founded in 1988 also compete locally and operated scheduled flights to both domestic and international destinations.

But each of these low-cost carriers are struggling during the off-seasons in order of the change of lifestyle-due to sluggish economic conditions (lack of passengers demand) and Covid19 pandemic. The lockdowns by countries in the region these low-cost carriers operated eventually has killed international travelling.

\subsection{AirAsia Company and the Business Model}

The AirAsia operating its subsidiaries like a franchise model, critics called these are provinces of Fernande's so called business Empire. The vision remains but mission of the AirAsia changed to ensure same strategy that the subsidiaries would operate to ensure revenue for the Malaysian parent company's grand vision of One AirAsia. The CEO strategized with an India's AirAsia affiliate was a larger play for the group.

With AirAsia already having a healthy presence in India that was an alluring for its expansion program in the West Asian skies but trouble began, as feeder airline here was supposed to help the Malaysian parent expand to provide a prelude for West Asian skies and beyond. Is it due to complacency or otherwise Tony missed on both the regulatory environment in India as well as the competition in the skies by low cost carriers?
The complacency is killer in an era of competition. Tony Fernandes is a celebrity in Malaysia but India is different. The political environment in India is skewed to different allies in business. In the meantime bribery scandal involving aircraft manufacturer Airbus put the nail in the coffin. Immediately he got cleared by the Malaysian law makers but this did not august well in a different political set up as this weakens his reputation and was forced to resign as group AirAsia CEO tarnishing once his heroic figure image in the industry.

Air Asia's strategy of everyone can fly is by counting on ancillary revenue. Besides, it offers tickets price at rock bottom on the other hand charges for all services including seats and baggage. Through forward integration practices enabled by online ticketing, AirAsia kills the distribution network and monopolized the market hence enjoyed cost leadership. The same did not work in India where small sales agent controls the market on commission. Indian regulator DGCA had summoned Air Asia to change its initial plan of no free baggage and lower its seat selection fees affected its business tactics. About 85 percent of AirAsia tickets are sold through its website, limiting agents' commission. Nevertheless in India, about 75 percent of tickets are sold through offline agents and portals as means to create more job opportunities to the locals. In Kuala Lumpur and Bangkok, AirAsia flies to low-cost terminals and by virtue of being the monopoly airline, negotiates very low rates from airports. Contrary to this India have no such facilities as low-cost terminals and attempts to coerce Delhi and Mumbai regular airports didn't work in the favour of the airline. Eventually, the CBI inquiry was instituted and case was filed in 2017 sealed the fate of his India's business plan for the AirAsia. Initiating and FIR against the unfair business practices by investigating agencies for bribery case did not go down well to obtain quick permission for international operations. It also negatively affected the relationship that oce existed with the local partners, Tatas that contemplated the host country partner for a merger plan with the Vistara's co-owner agenda in Singapore. Failing that AirAsia's frontline has to take back seat to allow full control in local hands. Hence Banmali Agrawal was appointed chairman by the virtue of being majority shareholder's discretion. Beside the chair operations in charge Sanjay Kumar a former Indigo executive was entrusted to navigate the venture in right direction. The airline gained market share but Kumar was hamstrung by Fernandes' declining interest in India due to controversy of appointing local agents that eventually annoyed Tony Fernandes, he quit.

\subsection{Financial Position of AirAsia}

An analysis of the numbers shows the airline isn't profitable even on a single route it operates. The group earnings after tax show a tremendous reduction from USD 254.78 million in 2010 to USD 133.3 million for the year 2011. In addition, a downward trend of their recent net income growth as portrayed in their statement of income is illustrated in the figure 1 below: 


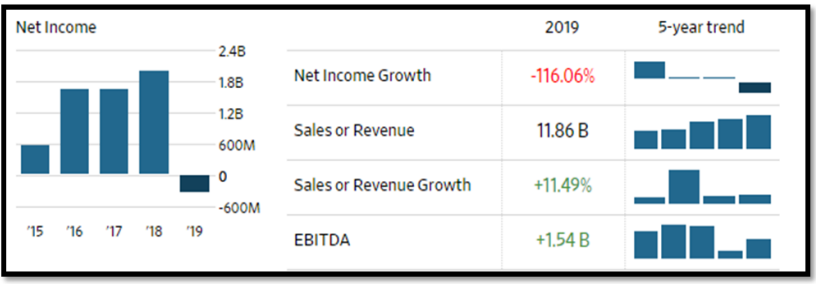

Figure 1: 5-year Trend Analysis of AirAsia Group Bhd [1].

Besides, GMT Research (2015) claimed that Indonesia AirAsia and AirAsia Philippines lately were seen not been able to pay AirAsia Berhad as debts due by related parties have distended which amounted from USD 40.81 million at the year-end of 2007 to USD 0.67 billion by end of first quarter 2015, with the sums owed surpassing the sales which those associates accumulate. It is not just the amounts owed by those affiliates that were the concern, rather, AirAsia Berhad had also been extending funds for working capital to its associates in Indonesia and the Philippines. In 2014, that amount was USD 0.26 billion and a further USD 77.53 million was extended in the first quarter of 2015. Dilemmas in its associates have now pulled the operating cash flows of AirAsia Berhad by 46 percent to USD 0.31 billion, which was not aided by AirAsia Berhad's spending on capital expenditure which was near to a record high. With the sum due by associates such as Indonesia AirAsia and AirAsia Philippines rising and stretched to 60 percent of shareholders' funds, a non-payment of that debt and a write-down would hurt the financials of AirAsia Berhad.

AirAsia India has now come to the highly expected final deal for $49 \%$ of its minority shares' interest invested by AAIL (AirAsia Investment Limited) to sell to local majority shareholder Tata group for an amount of approximately US\$ 38.00 million (RM 153 millions). This is the best deal for the group which is disposing of its 32.67 percent equity interest in AirAsia India Ltd (AAI) to Tata Sons Private Ltd (TSL). The remaining approximately $16 \%$ shares of the group will be subjected to future settlements in the year 2022 to make it AirAsia India fully diluted to become a local concern. However it didn't matter whether the majority partner to pay the licensor's fee for the deal with established norm of brand value or goodwill during valuation to appear in the balance sheet and the fee has gone for free to the Tata Sons. Despite this the group said it was a fair deal [2].

The group CEO justified by saying that the proposed disposal would result in a gain on disposal of RM152.58 million in the fourth quarter of 2020 at both AAIL and consolidated group levels. Accordingly, "the net assets and cash balance of AAIL will increase by the same amount immediately after this cash disposal exercise," it said.

It added that this waiver would not have any material effect on the earnings per share, net assets per share and gearing of AirAsia and its subsidiaries.

The original break-even target has been deferred twice. International operation of AirAsia India was the crux of
Tony's India plan. "When he realized, it wouldn't happen soon, the appetite for growth and expansion of so called business empire had slowed down. AirAsia India predicted it would break even in four months when it began flying in 2014. In reality, it has yet to make money in a market where high fuel taxes and cut-throat fares can make even dominant players unprofitable. The carrier has a market share of $6.8 \%$ and employs more than 3,000 people.

"There was a plan to have 30 aircraft by 2018 but Fernandes wouldn't approve," the board member said. The Tata imprint only got stronger. Henceforth the AirAsia India were in trouble and board members are under pressure to rationalization scheme and rescue plan in the best possible manner as a way forward for the Air Asia group of companies. And the affiliate turnaround plan end up that Air Asia India investment is divested and Tata Sons Private Ltd.is in full control. As a whole the pandemic has partially, if not completely, made revenue streams of Air Asia group fully paralyzed since international closed borders due to health concerns and covid-19 reason during almost the whole year2020 .

\section{THE TROUBLE IN THE SKY}

India's aviation minister said over the weekend that AirAsia was shutting up shop in the South Asian nation, though his office later suggested the comment was taken out of context by media persons. On the other hand, AirAsia also suffered a set-back earlier that its Japanese arm will cease flying immediately as the coronavirus outbreak continues to roil the airline industry. Once the the leader in low cost air travel of the region's revolution, the financial position of the group is seeking as much as RM2.5 billion to steer its way through the crisis.

AirAsia Group suffered and facing daunting task for handling the crisis and is filing with Bursa Malaysia that it was notified of the decision taken by the board of directors of AAJ to permanently suspend its operations with immediate effect.

Air Asia group have agreed to the decision made by AAJ as this would reduce the cash burn of AAJ and the company. This is amid the highly challenging operating conditions in Japan, which have been aggravated by the Covid-19 pandemic that has plagued the world since early this year.

He said Maybank IB expects AirAsia Group to recognise its share of loss from AAJ at about RM164 million and RM146 million respectively for FY20 and FY21. Accordingly, it is believed AirAsia Group is at risk of more capital raising exercises (cash calls) and potential industry restructuring to keep the group's operations afloat during this critical period," Wong said.

The analyst said Maybank IB had upgraded its call for AirAsia Group shares to "hold" from "sell" while maintaining its TP at 67 cents for the stock. On Bursa Malaysia currently, AirAsia Group's share price had risen half a cent or $0.78 \%$ to 65 cents as at the time of writing, which valued the company at about 
RM2.17 billion. As pointed out by the analyst, "We may turn even more positive should AirAsia Group cease the operations of 49\%-owned AirAsia India (AAI) as well. For FY20/FY21, we forecast AirAsia Group to recognise its share of loss from AAI as a larger RM325 million/RM275 million," Yin said.

AirAsia India has survived on 3 billion rupees (approximately RM 170 million) in funding from Tata, which owns a 51\% stake, with another round of financing expected soon, one of the people said. Tata is weighing its options and how much it would cost to buy out AirAsia and save the carrier, another person said. The industrial group also has a $51 \%$ holding in the Vistara full-service airline venture with Singapore Airlines Ltd.

Long-haul arm AirAsia-X Bhd has meanwhile said it needs to reach deals with major creditors to restructure debt amid "severe liquidity constraints" that threaten its ability to resume services and continue as a going concern.

\section{\& 4. PRESENT POSITION PROTAGONIST SAY}

AS

AirAsia India Ltd.'s future hinges upon the host and majority stakeholder, Tata Group. The host has provided emergency funding. Nevertheless there is a limit and yet to commit to a full rescue, according to the people in the helm of the affairs. Partners are discussing the matter openly for otherwise a confidential matter. The airline isn't at any immediate risk of folding but the people hardly buy it as reasonable statements.

The protagonists are the top managers who are currently entrusted to developing sustainable strategy in the face of rising costs of operations for the airlines in a highly competitive environment and no revenue generation during the lockdowns due to the Covid-19 still believed that the troubled airline will pull it out sooner than later. The reason for their strong belief is the diversification strategy its group CEO has in mind as a sustainable business plan. Recently, the airline company engaged Navitaire - a technology entity to build its own booking website. This would be a first for any airline in the AirAsia group for such an arrangement. On the other side the globally renowned "Tata Consultancy Services (TCS)" which is an IT outfit is tasked to build a crew scheduling software. Previously this used to be handled from Kuala Lumpur.

\subsection{Crisis Management in the East and West}

The business risk due to pandemic still around and the future forecast holds uncertainty. A cursory look at the spread of the virus in India was initially detected on March 17, 2020, whereas in the United States, Europe and in the West was earlier. But the global scenario of the pandemic suggested that in the first two months, while India fared worse than its counterparts- Singapore, Malaysia, Indonesia, Japan and South Korea in the East but it fared much better compared to the US and the United Kingdom in the West. The pandemic has delayed further any recovery if not some plans, but as and when it happens it will be a complete breakaway from Fernandes' AirAsia vision.

The health concerns and uncertain situations due to hardly seen stable economic environment contributed a pessimistic future outlook of airlines industry. The only hope of anti-virus vaccines' arrival in near future can guarantee the opening of tourism sector and business traveling. The direct impact of such a slow down on turnaround is mere speculation. Thus far the blinking business environment for the industry is the reality of the day.

\subsection{Blinking Business Environment}

Recently released reports by the Japanese think tank on the response to the Covid-19 epidemic in 49 major countries around the world, Malaysia scored second with a comprehensive score of 144 . By and large in our evaluation report, Taiwan is only country in the region has achieved an excellent result in its' assessment of the pandemic so far and the economic recovery status is somehow satisfactory and earned 180 out of the overall score of 200 score points in the ranking as being first in the world at a material time. In the neighborhood of Taiwan.

Hong Kong ranked third with 143 points. But Thailand, China and South Korea, Australia and New Zealand (99 points) ranking from 4th to 10 th) 126 points, 124 points, 120 points, 99 points respectively. According to another report, the USA has attracted much attention due to the severe epidemic, ranked 41st, and India now followed as the next worse after the United States and air traveling in India was banned altogether with a very few exception until recently.

The Southeast Asian countries were the best in the rankings until recently because these countries have paid attention to the pandemic and health conditions in early detection and implemented immigration control to preempt which has exerted the greatest effect. The report pointed out that the emphasis on the trend of epidemic damage and economic damage including aviation business is still related to how flexible a country is to react to the situation and opening economic activities standstill due to lockdowns. Malaysia has now rang the alarm bell due to the so called third round due to some lapses and country again clamp the lockdown that badly hit the air traveling. However, because the health crisis and continues pandemic is on-going and the outcome situation of these countries may change over a period of time subject to the availability of vaccines earlier than expected will continue to affect the business plan of aviation industry.

\section{EPILOGUE}

There is always an opportunity in challenges for innovation in related business or turnaround strategies are followed by fallen hero however things have become harder for the AirAsia group $\mathrm{CEO}$ at home too. By all the definitions the current liabilities of AirAsia exceeded its assets. Once a hero and ever established the business tycoon is appealing to the government of Malaysia a temporary bailout as last resort for survival. The 


\section{Business and Management Research (IJBMR)}

Case Study | Volume 9, Issue 1 | Pages 1-5 | e-ISSN: 2347-4696

board member quoted that the situation above created the cash crisis and that was acute for Fernandes. Therefore infusing cash into the AirAsia India would be formidable and difficult task ahead rather look forward to an alternative source of liquidity. "That has been a bone of contention."

Tata's group may provide a one-time emergency funding, but increasing exposure in an airline with little chance of profitability in the near future is not on the majority shareholders agenda. In line with the new management's opinion, "we have been directed to shelve all growth plans and cut losses," the group said.

The AirAsia India spokesperson refused to comment but the group CEO of AirAsia Fernandes has indicated that he's contemplating to exit the venture. Based on the case facts and the pandemic still around have made his job difficult.

"Who in their right mind will buy his stake in an airline industry and grounded aircrafts which has no strong indication of recovery soon, no growth plans, no aircraft ordered and booked previously, if at all, it has to be a distressed sale," an investment banker said. A Goan Indian originated but a Malaysian presently, Tony Fernandes, who once used to call India as his ancestral home, now makes little sense to continue his venture and the eventual outcome was in a wait and see that finally on sale is concluded this case.

\section{QUESTIONS}

1. Looking at the grim situations created around by the Pandemic and continuous lockdown with no signs of resumption of airlines to take off, if any with the tight SOPs fly half-empty due to social distancing, do you think that Air Asia will survive without a bailout?

2. Is the business model of centralised control by the group CEO-Fernandes will be able to sustain in India's present business uncertainties, economic downturn and hostile political environment?

3. AirAsia India and CEO Sunil Bhaskaran, a former Tata Steel executive, is implementing a cost control project originally conceptualized by Tata Steel boss $T$ $\mathrm{V}$ Narendran to look an alternative for other than the AirAsia India as its divestment as an strategic option? Note: For teaching notes, contact the author.

\section{REFERENCES}

[1] Five Year Trend of Air Asia Group Bhd. 2020. Wall Street Journal Markets.

[2] Security Exchange (KLSE), 2020. AirAsia - Money Matters, Bernama, Kuala Lumpur, 29 Dec, 2020.

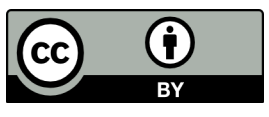

(C) 2021 by the Dr. Khaliq Ahmad Mohammad. Submitted for possible open access publication under the terms and conditions of the Creative Commons Attribution (CC BY) license (http://creativecommons.org/licenses/by/4.0/). 